\title{
Reorientasi Pendidikan Kebangsaan Berbasis Adab: Konsep dan Problematiknya
}

\author{
Dikdik Baehaqi Arif \\ Universitas Ahmad Dahlan Yogyakarta \\ Email: dikdikbaehaqi@ppkn.uad.ac.id
}

\begin{abstract}
ABSTRAK
Secara tegas, di antara tujuan awal penyelenggaraan pendidikan nasional selain membentuk peserta didik menjadi manusia yang beriman dan bertakwa kepada Tuhan Yang Maha Esa adalah membentuk manusia berakhlak mulia. Dalam konteks demikian, pendidikan kebangsaan yang dititipkan melalui pembelajaran PPKn dapat diselenggarakan dengan bersandar pada nilai-nilai budi/akhlak/ kebajikan utama warga negara. Hal itu sebagai ikhtiar untuk menjaga dan merawat rajutan kebangsaan Indonesia yang bersatu di atas dasar falsafah Pancasila dan dasar konstitusional UUD 1945. Menjadikan adab sebagai basis penguatan wawasan kebangsaan memerlukan komitmen dari seluruh komunitas akademik PPKn. Diperlukan kajian-kajian akademis pedagogis untuk praxis penyelenggaraan pendidikan kebangsaan yang berkemajuan agar misi pendidikan kebangsaan melalui PPKn menjadi bidang kajian yang kuat dan berkontribusi besar bagi penguatan akhlak utama warga negara demi terwujudnya cita-cita dan tujuan Indonesia berkemajuan.
\end{abstract}

Kata kunci: pendidikan kebangsaan, PPKn, Indonesia berkemajuan, adab, akhlak, ta'dib, tarbiyah, ta'lim

\section{PENDAHULUAN}

\section{Potensi bangsa Indonesia} untuk menjadi negara yang maju, modern, dan beradab sangat tinggi. Namun, potensi besar yang dimiliki oleh Bangsa Indonesia belum sepenuhnya dapat diwujudkan menjadi prestasi yang menyejahterakan rakyat Indonesia (Nurihsan, 2016). Dari sisi pendidikan misalnya, Bank Dunia menyebut bahwa kualitas pendidikan di Indonesia masih rendah, meski perluasan akses pendidikan untuk masyarakat dianggap sudah meningkat cukup signifikan (CNN Indonesia, 2018). Komnas HAM (Nadlir, 2018) bahkan mencatat empat darurat pendidikan, yaitu pelanggaran HAM dalam dunia pendidikan, ranking pendidikan Indonesia yang rendah, kondisi darurat yang terjadi lantaran banyak kasus korupsi yang berkaitan dengan anggaran pendidikan, dan keempat sistem pendidikan yang belum berjalan dengan baik. Di sisi lain Menteri Pendidikan dan Kebudayaan menyebut problem pendidikan saat ini adalah kurangnya keteladanan (Kompas, 2018).

Persoalan pendidikan itu ditambah dengan adanya fenomena degradasi moral di kalangan peserta didik. Sebut saja, ada pelajar yang terpapar dan terlibat tindakan- 
tindakan kriminalitas, penyalahgunaan narkotika dan obat-obat terlarang, perilaku seks bebas, tawuran, rendahnya penghormatan murid kepada guru, dan sederet perilaku yang menunjukkan degradasi moral lainnya. Ada juga fenomena dimana peserta didik terpapar paham radikalisme (Republika, 2018). Berbagai fenomena itu "selalu" menjadikan pendidikan, khususnya guru sebagai "tertuduh" yang menyebabkan rendahnya kualitas pendidikan Indonesia. Karena itu, isu tentang perbaikan sektor pendidikan di Indonesia selalu menjadi bahan diskusi yang tidak pernah selesai.

Dilihat dari perspektif pedagogik, di antara faktor yang turut mempengaruhi persoalan-persoalan di atas adalah "hilangnya adab (loss of $a d a b)$ dalam proses pendidikan (Husaini, 2016). Adab menjadi hal penting dalam proses pendidikan, sebab sejatinya fungsi dan tujuan utama pendidikan adalah untuk melahirkan manusia yang beradab. Karena itulah, sudah sepatutnya dunia pendidikan menekankan pada proses ta'dib, yaitu sebuah proses pendidikan yang mengarahkan para siswanya menjadi orang-orang yang beradab (Husaini, 2010). Proses pendidikan berbasis adab itu selanjutnya menjadi tugas mulia guru. Fokus tulisan ini membahas upaya memperkuat pendidikan kebangsaan dengan mengangkat nilai-nilai budi/akhlak/kebajikan utama warga negara yang bersumber pada nilai-nilai Islam sebagai proses ta'dib. Pendidikan kebangsaan dalam tulisan ini dimaknai sebagai misi dari mata pelajaran PPKn sebagai kajian kurikuler kewarganegaraan di persekolahan (school civic education). Secara rinci, artikel ini mengkaji pendidikan, adab, dan peradaban; Akhlak sebagai jantung peradaban; Problematik pendidikan berbasis adab; Pendidikan kebangsaan dan Indonesia berkemajuan; Islam dan pendidikan kebangsaan; dan reorientasi pendidikan kebangsaan dan peran guru. Tawaran adab dalam pendidikan kebangsaan diharapkan mampu mendorong penguatan pemahaman dan keterlibatan warga dalam mewujudkan Indonesia berkemajuan sebagai negara utama, berkemakmuran dan berkeadaban, dan negara yang sejahtera sebagai cita-cita dan tujuan utama bernegara.

\section{METODE PENELITIAN}

Dalam penelitian ini peneliti mengunakan metode penelitian pustaka (library research). Dalam penelitian pustaka ini sumber data yang berupa literatur-litelatur yang mendukung pembahasan dalam penelitian menjadi acuan utama. Sehingga kegiatan penilitian ini dengan mengumpulkan data pustka, membaca dan mengolah data serta menghasilkan analisis dan temuan dari hasil olah data. 


\section{PEMBAHASAN}

\section{Pendidikan, Adab, dan Peradaban}

Sebuah pantun ditulis Buya Hamka (2016a) tentang pentingnya budi,

Tegak rumah karena sendi

Runtuh sendi rumah binasa

Sendi bangsa ialah budi

Runtuh budi runtuhlah bangsa

Pantun tersebut menegaskan posisi budi (kebajikan/keutamaan/akhlak warga bangsa/civic virtue) dalam membangun bangsa. Demikian pentingnya budi, sampai-sampai keruntuhan budi menjadi sebab utama runtuhnya bangsa. Dalam sebuah nasihat tentang budi dan adab, Mawardi (Husaini, 2016) misalnya menguraikan dari adab yang buruk akan lahir rusaknya akal; rusaknya akal akan menimbulkan kebiasaan yang buruk; dari kebiasaan yang buruk akan lahir karakter yang jahat; dari karakter yang jahat akan lahir amalan yang buruk; dan amalan yang buruk akan mendatangkan kemurkaan Allah; dan kemurkaan Allah itu akan menyebabkan kehinaan selamalamanya. Pantun Hamka (2016a) juga mengisyaratkan perlunya merawat bangsa melalui penguatan kebajikan/ keutamaan/akhlak warga bangsa.

Bangsa Indonesia dalam pandangan Anderson (Dhakidae, 2002), adalah sebuah komunitaskomunitas terbayang (imagined community), karena para anggota bangsa terkecil sekalipun tidak bakal tahu dan tidak kenal sebagian besar anggota lain, tidak akan bertatap muka dengan mereka itu, bahkan mungkin tidak pula pernah mendengar tentang mereka. Kebhinnekaan suku bangsa, ras, agama, budaya, adat istiadat memperkaya kebangsaan Indonesia. Ia menjadi modal sosial dan budaya (cultural and social capital) yang menjadi pengikat kelompokkelompok masyarakat yang berbeda latar belakang untuk bersatu sebagai bangsa Indonesia. Namun, pada sisi yang lain, keberagaman ini juga rawan dengan konflik antar entitas yang berbeda yang pada gilirannya dapat meruntuhkan sendi-sendi kehidupan berbangsa dan bernegara yang kuat.

Memperkuat kebajikan warga bangsa menjadi penting dilakukan, karena ia memiliki peran sentral dalam meneguhkan identitas warga bangsa - yang dibangun atas dasar entitas yang berbeda - yang berakhlak dan bermartabat. Lebih luas dari itu, dalam konteks kenegaraan penguatan adab/kebajikan warga bangsa juga untuk mendorong penguatan pemahaman dan keterlibatan warga dalam mewujudkan Indonesia berkemajuan sebagai negara utama (al-madinah al-fadhillah), berkemakmuran dan berkeadaban (umran), dan negara yang sejahtera (Nashir, 2015) sebagai cita-cita dan tujuan utama bernegara.

Pendidikan adalah alat utama untuk memperkuat budi warga dalam merawat bangsa. Dalam rumusan sistem pendidikan nasional, penyelenggaraan pendidikan nasional hadir tidak semata untuk membentuk manusia yang cerdas dan terampil, tetapi yang utama adalah menjadi manusia yang beriman dan bertakwa kepada Tuhan Yang Maha Esa, serta menjadi warga negara yang demokratis dan bertanggungjawab (Undang-Undang Republik Indonesia No. 20 Tahun 2003 Tentang Sistem 
Pendidikan Nasional, 2003). Di sanalah, urgensi peneguhan budi warga bangsa dikuatkan melalui pendidikan.

Pendidikan dapat diberi makna baik secara khusus (sempit) maupun secara luas (umum). Pendidikan dalam arti khusus adalah bimbingan yang diberikan oleh orang dewasa kepada anak yang belum dewasa untuk mencapai kedewasaannya dalam arti rohani dan jasmani (Langeveld, 1965), termasuk di dalamnya adalah agar anak itu kelak cakap menyelesaikan tugas hidupnya atas tanggung jawab sendiri (Ahmadi \& Uhbiyati, 1991) menuju terbentuknya kepribadian yang utama (Marimba, 1989, hal. 23).

Pendidikan dalam arti sempit itu menunjukkan bahwa pendidikan hanya melibatkan pengaruh orang lain (tidak melibatkan pengaruh diri sendiri, kebudayaan, dan alam sekitar atau lingkungan peserta didik) terhadap perkembangan pribadi peserta didik atau ia terbatas pada kegiatan pengembangan jasmani dan rohani peserta didik. Bagi Saduloh (2004, hal. 55), pendidikan dalam arti khusus menggambarkan upaya pendidikan yang terpusat dalam lingkungan keluarga. Pendidikan hanya dibatasi sebagai usaha orang dewasa dalam membimbing anak yang belum dewasa untuk mencapai kedewasaannya. Setelah anak menjadi dewasa dengan segala cirinya, maka pendidikan dianggap selesai.

Secara luas, Tafsir (2004) mendefinisikan pendidikan sebagai pengembangan pribadi dalam semua aspeknya. Dengan penjelasan bahwa yang dimaksud pengembangan pribadi ialah yang mencakup pendidikan oleh diri sendiri, pendidikan oleh lingkungan dan pendidikan oleh orang lain (guru). Seluruh aspek mencakup jasmani, akal, dan hati.

Dari pengertian tersebut, dapat dipahami bahwa pendidikan dalam arti luas berlangsung pada tiga lingkungan pendidikan, yaitu keluarga, sekolah, dan masyarakat. Serta ada tiga ranah pendidikan, yaitu jasmani, akal, dan hati. Pendidikan juga adalah usaha manusia untuk meningkatkan kesejahteraan hidupnya, yang berlangsung sepanjang hayat. Tentang hal tersebut, menarik pengertian pendidikan yang dikemukakan Henderson (1959)

Pendidikan merupakan suatu proses pertumbuhan dan perkembangan, sebagai hasil interaksi individu dengan lingkungan sosial dan lingkungan fisik, berlangsung sepanjang hayat sejak manusia lahir. Warisan sosial merupakan bagian dari lingkungan masyarakat, merupakan alat bagi manusia untuk pengembangan manusia yang terbaik dan cerdas, untuk meningkatkan kesejahteraan hidupnya.

Pendidikan bukan hanya untuk kesejahteraan hidup manusia, tetapi harus mampu menanamkan nilai-nilai keimanan dan idealisme pada diri peserta didik. Bahkan lebih dari itu, pendidikan pun harus berupaya melestarikan dan mengusung 
kebudayaan bangsa (Nurihsan, 2016, hal. 1).

Secara luas, makna pendidikan juga dikemukakan oleh Sudjana (1988, hal. 2) sebagai

1) upaya memanusiakan manusia yang pada dasarnya adalah upaya mengembangkan

kemampuan/potensi

individu sehingga bisa hidup optimal baik sebagai pribadi maupun sebagai anggota masyarakat serta memiliki nilai-nilai moral dan sosial sebagai pedoman hidupnya

2) usaha sadar yang bertujuan dan usaha mendewasakan anak

3) proses budaya untuk meningkatkan harkat dan maratabat manusia, melalui proses yang panjang dan berlangsung sepanjang hayat

Dari perspektif Islam, rekomendasi dari Konferensi Internasional Pendidikan Islam pertama (First World Conference on Moslem Education) di Universitas King Abdul Aziz, Jeddah pada tahun 1977 memberi kesimpulan bahwa pendidikan adalah keseluruhan pengertian yang terkandung dalam istilah ta'lim, tarbiyah, dan ta'dib (Tafsir, 2004). Ta'dib secara bahasa merupakan bentuk (masdar) kata kerja addabu yang dapat diterjemahkan sebagai mendidik, undangan perjamuan, kebudayaan, tata tertib social, kehalusan budi, ketertiban, kebiasaan yang baik, kepantasan, kemanusiaan dan kesusastraan. Dari arti tersebut, para ulama klasik menerjemahkan kata ta'dib sebagai kepintaran, kecerdikan, dan kepandaian. Dalam Bahasa Indonesia, $a d a b$ berarti sopan, kesopanan, kebaikan (budi pekerti) dan kehalusan (Tafsir, 2004, hal. 29).

Makna tarbiyah adalah proses pengasuhan pada fase permulaan pertumbuhan manusia. Bagi Taftazani dan Abdurrahman (2005) Al-Tarbiyah adalah proses pengembangan, pemeliharaan, penjagaan, pengurusan, penyampaian ilmu, pemberian petunjuk, bimbingan, penyempurnaan, dan perasaan memiliki bagi anak didik baik jasad, akal, jiwa, bakat, potensi, perasaan, secara berkelanjutan, bertahap, penuh kasih sayang, penuh perhatian, kelembutan hati, menyenangkan, bijak, mudah diterima, sehingga membentuk kesempurnaan fitrah manusia, kesenangan, kemuliaan, hidup mandiri, untuk mencapai ridha Allah swt.

Sementara itu, istilah ta'lim tidak berhenti pada pengetahuan yang lahiriah, juga tidak hanya sampai pada pengetahuan taklid. Ta'lim mencakup pula pengetahuan teoretis, mengulang kaji secara lisan dan menyusul melaksanakan pengetahuan itu. Ta'lim juga mencakup aspekaspek pengetahuannya serta keterampilan yang dibutuhkan dalam kehidupan serta pedoman berperilaku.

Al-Attas (Tafsir, 2004) menganggap istilah ta'dib adalah istilah yang paling tepat untuk menggambarkan pengertian pendidikan, sebab struktur konsep ta'dib telah mencakup unsur-unsur ilmu ('ilm), instruksi (ta'lim), dan 
pembinaan yang baik (tarbiyah) sehingga tidak perlu lagi dikatakan bahwa konsep pendidikan Islam adalah sebagaimana terdapat dalam tiga serangkai konsep tarbiyah, ta'lim, dan ta'dib.

$$
\text { Ta'dib menurut Al-Attas }
$$

(Daud, 1998, hal. 174) adalah "penyemaian dan penanaman adab dalam diri seseorang". Pandangan ini diikuti pula oleh Djawad Dahlan (Nurihsan, 2016, hal. 11) yang menyebut pendidikan sebagai penyemaian dan penanaman adab (ta'dib) secara utuh, dalam upaya mencontoh utusan Allah, Nabi Muhammad Saw., sehingga menjadi manusia sempurna. Bagi Djawad Dahlan (Nurihsan, 2016, hal. 11), pendidikan dimaknai sebagai

upaya menumbuhkan manusia menuju dunia lain yang lebih tinggi, tidak sekedar berada di dalam hidup instinktif. Dunia yang lebih tinggi ini dapat dicapai dengan usaha sadar untuk menentukan berbagai pilihan yang tersedia bagi manusia. Pendidikan diarahkan agar manusia mampu menjalankan fungsi kemanusiaan sebagai hamba Allah dan sebagai khalifah di bumi secara universal (Nurihsan, 2016, hal. 11).

Ta'dib tidaklah sekadar proses transfer ilmu (ta'lim), tetapi juga pengaktualisasiannya dalam bukti (QAnees \& Hambali, 2008, hal. 30), karena itu, ia meliputi "pengenalan" dan "aktualisasi". Dalam istilah ta'dib, pendidikan berarti pengenalan dan pengakuan yang secara berangsur-angsur ditanamkan kepada manusia, tentang tempat-tempat yang tepat bagi segala sesuatu dalam tatanan wujud sehingga hal ini membimbing ke arah pengenalan dan pengakuan tempat Tuhan yang tepat di dalam tatanan wujud tersebut.

Pengenalan terkait dengan konsep perjanjian primordial, ia berarti kembali mengingat (recognize). Pengenalan ini tidak hanya berhubungan dengan diri manusia (manusia mengenali diri pada saat perjanjian primordial dengan Tuhannya), melainkan juga pada seluruh semesta. Tugas pendidikan adalah mengenali kembali apa yang telah ada pada tempatnya masing-masing dalam pelbagai hierarki wujud. Sedangkan pengakuan berarti melakukan afirmasi, aktualisasi di dalam diri seseorang mengenai apa yang sudah dikelanya itu dalam tindak nyata dan realitas.

Prinsip-prinsip dasar pendidikan bagi Al-Attas (Daud, 1998, hal. 177) meliputi uraian berikut:

Orang baik adalah yang mendasari sepenuhnya tanggung jawab dirinya kepada Tuhan Yang Hak; yang memahami dan menunaikan keadilan terhadap dirinya sendiri dan orang lain dalam masyarakatnya; yang terus berupaya meningkatkan setiap aspek dalam dirinya menuju kesempurnaan sebagai manusia yang beradab.

Prinsip-prinsip dasar pendidikan itu, sejalan dengan arah utama pendidikan. Bagi Mohammad Natsir, seorang guru Persatuan Islam, tauhid adalah dasar utama pendidikan. 
Dalam salah satu pidatonya, Natsir pernah menyampaikan:

Mengenal
mentauhidkan Tuhan,
mempercayai $\begin{array}{r}\text { Tuhan, } \\ \text { dan }\end{array}$
menyerahkan diri kepada
Tuhan, tak dapat tidak harus
menjadi dasar bagi tiap-tiap
pendidikan yang hendak
diberikan kepada generasi
yang kita latih, jikalau kita
sebagai guru ataupun sebagai
ibu-bapak, betul-betul cinta
kepada anak-anak yang telah
dipertaruhkan Allah kepada
kita (Natsir, 1973, hal. 142).

Pendidikan terjadi melalui interaksi insani tanpa batasan ruang dan waktu. Pendidikan tidak mulai dan diakhiri di sekolah. Pendidikan dimulai dari lingkungan keluarga, sekolah dan masyarakat dan hasilhasilnya digunakan dalam membangun kehidupan pribadi, agama, keluarga, masyarakat, bangsa dan negaranya". Pekerjaan mendidik memerlukan tanggung jawab lebih besar daripada mengajar, karena mendidik seperti dikemukakan Rasyidin (2007) ialah "membimbing pertumbuhan anak, jasmani dan rohani dengan sengaja" bukan saja untuk kepentingan pengajaran sekarang melainkan utamanya untuk kehidupan seterusnya di masa depan.

Pendidikan pada hakikatnya akan mencakup kegiatan mendidik, mengajar, dan melatih. Pendidikan dilaksanakan sebagai usaha untuk mentransformasikan nilai-nilai. Karena itu, dalam pelaksanaannya, ketiga kegiatan tersebut harus berjalan secara terpadu dan berkelanjutan serta serasi dengan perkembangan peserta didik dan lingkungan hidupnya. Nilai-nilai yang ditransformasikan tersebut meliputi nilai-nilai religi, kebudayaan, sains dan teknologi, seni, dan keterampilan. Nilai-nilai tersebut ditransformasikan untuk mempertahankan, mengembangkan, bahkan mengubah kebudayaan yang dimiliki masyarakat (Saduloh, 2004, hal. 57). Merujuk pada gambaran tersebut, dapat dikemukakan bahwa pengajaran hanyalah salah satu usaha yang dapat dilakukan melalui pendidikan dalam mendidik anak didiknya.

Ahli tafsir Indonesia, $\mathrm{M}$ Quraish Shihab membedakan arti pendidikan dan pengajaran. Ia mendasari pendapatnya dengan menafsirkan QS Al Jumu'ah ayat 2. Menurut Shihab (1992, hal. 172) kata menyucikan dalam ayat tersebut dapat diartikan dengan mendidik, sedangkan mengajar adalah mengisi benak anak didik dengan pengetahuan yang berkaitan dengan alam metafisika serta fisika.

Mendidik lebih luas daripada mengajar, sebab dalam konteks mendidik seakan-akan pendidik akan ikut menentukan masa depan sang anak dalam jangka panjang, sehingga pendidik tak boleh membuat kesalahan-kesalahan (Rasyidin, 2007). Sementara mengajar adalah menyajikan bahan ajar tertentu berupa seperangkat pengetahuan, nilai dan/atau deskripsi keterampilan kepada seseorang atau sekumpulan orang/anak dengan maksud agar pengetahuan yang diperlukannya sekarang ataupun untuk pekerjaan yang akan dijalaninya bertumbuh sehingga ia mampu mengembangkan atau meningkatkan inteligensinya secara intelektual (Rasyidin, 2007). 
Lalu, apa sebenarnya konsep $a d a b$ ? Uraian yang lebih rinci tentang konsep adab dalam Islam disampaikan oleh Syed Muhammad Naquib al-Attas, pakar filsafat dan sejarah Melayu. Menurut al-Attas (Al-Attas, 2001) adab adalah "pengenalan serta pengakuan akan hak keadaan sesuatu dan kedudukan seseorang, dalam rencana susunan berperingkat martabat dan darjat, yang merupakan suatu hakikat yang berlaku dalam tabiat semesta." Pengenalan adalah ilmu; pengakuan adalah amal. Maka, pengenalan tanpa pengakuan seperti ilmu tanpa amal; dan pengakuan tanpa pengenalan seperti amal tanpa ilmu" Keduanya sia-sia kerana yang satu menyifatkan keingkaran dan keangkuhan, dan yang satu lagi menyifatkan ketidaksadaran dan kejahilan.

Nurihsan (2016) menyitir pandangan B. J. Habibie yang menjelaskan bahwa ada tiga tiang peradaban yang perlu dikembangkan untuk membangun peradaban Indonesia yang maju, sejahtera, mandiri dan kuat, yaitu manusiamanusia Indonesia yang memiliki keunggulan "Ho2", "Hati" (iman dan taqwa), "Otak" (ilmu pengetahuan), dan "Otot" (teknologi). Bagi Nurihsan (2016) unsur pokok suatu peradaban adalah agama dan tradisi keilmuan yang dibangun melalui pendidikan yang bermutu. Serta hal yang sangat esensial dalam membangun peradaban Bangsa Indonesia adalah mengembangkan sumber daya manusia Indonesia yang bermutu yang dilakukan melalui pendidikan yang bermutu. Mengapa agama? Karena agama akan memalingkan jiwa dari hawa nafsunya dan melembutkan hati atas keinginannya. Agama adalah fondasi terkuat bagi kebaikan dan keberdirian dunia. Agama adalah tali kekang bagi manusia. Agama adalah sendi keadilan dan kebaikan.

Pendidikan yang bermutu adalah pendidikan yang mampu mengantarkan peserta didik memenuhi kebutuhannya, baik saat ini maupun di masa yang akan datang. Kebutuhan peserta didik ini merupakan atribut-atribut yang menjadi dasar standar mutu pendidikan. Atribut kebutuhan peserta didik ini tercantum dalam Undang-Undang Republik Indonesia Nomor 20 Tahun 2003 tentang Sistem Pendidikan Nasional. Pendidikan tidaklah bebas nilai, ia harus bersandar pada nilai moral keagamaan yang menempatkan Tuhan sebagai sumber kebenaran. Pernyataan Cristopher Dawson (Nurihsan, 2016), bahwa agamaagama besar merupakan fondasi dari peradaban-peradaban besar sebagai kelanjutannya menunjukkan bahwa pembangunan peradaban tidaklah meninggalkan nilai-nilai agama, tetapi sebaliknya ia harus bersandar dari nilai agama yang kuat, yaitu nilai-nilai yang bersumber dari Tuhan yang memiliki sifat mutlak.

Dalam konteks filsafat pendidikan, penempatan agama sebagai fondasi bagi peradaban bangsa melalui pendidikan, sesungguhnya merupakan perpaduan dari dua pemikiran filsafati yaitu intellectus quaerens fidem (pikiran lebih penting dari keimanan) sebagaimana dikembangkan oleh filsafat Helenisme dan pemikiran fides quaerens intellectum (keimanan lebih penting dari pikiran) yang merupakan tradisi filsafat Semitisme. 
Kedua tradisi pemikiran filsafat ini, tampak dalam rumusan fungsi dan tujuan pendidikan nasional sebagaimana termuat dalam UU No. 20 Tahun 2003 tentang Sistem Pendidikan Nasional.Negara-negara besar dapat mencapai peradaban dengan membangun tradisi keilmuan yang kuat. Negara dibangun di atas tradisi keilmuan. Tradisi keilmuan dibangun oleh pendidikan yang bermutu.

Dua unsur pokok peradaban (agama dan tradisi keilmuan) juga pernah dikupas Hamka (2017) yang ditulis dalam buku Renungan Tasawuf. Melalui buku tersebut, Hamka (2017) membahas secara rinci satu bab tentang Ilmu dan Khayal (hal. 1-20) yang oleh Hamka disebut syarat kunci peradaban (tamadun), baik pada peradaban Barat maupun peradaban Timur. Dengan Bahasa sastranya yang indah, Hamka (2017) menyebut bahwa khayal adalah anugerah ketuhanan, dan akal adalah pelita kemanusiaan.

Dalam pandangan Hamka, tamadun (peradaban) yang dicapai Barat sekarang ini, adalah saripati daripada berbagai tamadun yang telah ada; Yunani, Rumawi; zaman pertengahan renaissance dan zaman baru. Tapi isinya hanya satu, yaitu akal (Hamka, 2017, hal. 2). Di Timur pun terdapat tamadun besar. Saripati dari tamadun yang aneka warna. Sejak Tiongkok, India, Persi, Babilon, Ninive (Ninawa), Arab, dan lain-lain, tetapi isinya satu pula, yaitu kekayaan khayal (Hamka, 2017, hal. 2). Akal dan khayal yang digambarkan Hamka sebagai pendorong peradaban Barat dan Timur, adalah ibarat ilmu (akal) dan agama (khayal) yang memacu lahirnya peradaban tersebut. Akal didukung oleh proses penyelidikan, percobaan, dan pengalaman. Sedangkan khayal ibarat surya yang memberikan terang yang gelap, yang seribu pelita pun tidak dapat mengisinya.

\section{Akhlak sebagai Jantung Peradaban}

Jantung peradaban adalah akhlak (Nurihsan, 2016). Akhlak adalah sikap dan perilaku yang bersifat konstan, spontan, tidak temporer dan tidak memerlukan pemikiran dan pertimbangan, serta dorongan dari luar (Ilyas, 2015). Akhlak dan peradaban tidak pernah terpisahkan. Peradaban dan akhlak ibarat jasad dan ruh. Bila ruh sirna, maka sirna pula jasad yang fana itu (Nurihsan, 2016). Karenanya, jatuh bangunnya sebuah peradaban sangat ditentukan oleh akhlaknya. Selama akhlak suatu kaum masih bertahan, maka kaum itu akan bertahan. Sebaliknya bila akhlak kaum itu sirna, maka lenyap pula eksistensi peradaban kaum itu.

Akhlak secara etimologis adalah bentuk jamak dari khuluq yang berarti budi pekerti, perangai, tingkah laku atau tabiat, berakar dari kata khalaqa yang berarti menciptakan. Seakar dengan kata Khaliq (pencipta), makhluq (yang diciptakan) dan khalq (penciptaan) (Ilyas, 2015). Akhlak menempati kedudukan yang istimewa dan sangat penting. Di dalam alQur'an saja ditemui lebih kurang 1500 ayat yang berbicara tentang akhlak - dua setengah kali lebih banyak daripada ayat-ayat tentang hukum - baik yang teoretis maupun yang praktis. Belum terhitung lagi hadis-hadis Nabi, baik perkataan maupun perbuatan, yang memberikan 
pedoman akhlak yang mulia dalam seluruh aspek kehidupan.

Akhlak dalam Islam bukanlah

moral yang kondisional dan situasional, tetapi akhlak yang benarbenar memiliki nilai yang mutlak. Nilai-nilai baik dan buruk, terpuji dan tercela berlaku kapan dan di mana saja dalam segala aspek kehidupan, tidak dibatasi oleh waktu dan ruang (Maarif, 2015). Ajaran akhlak dalam Islam sesuai dengan fitrah manusia. Manusia akan mendapatkan kebahagiaan yang hakiki bila mengikuti nilai-nilai kebaikan yang diajarkan oleh al-Qur'an dan Hadis, dua sumber akhlak Islam. Akhlak Islam benar-benar memelihara eksistensi manusia sebagai makhluk terhormat, sesuai dengan fitrahnya itu

Jika sebuah bangsa dalam kehidupannya telah menunjukkan perilaku yang bermoral, cerdas, menguasai ilmu pengetahuan dan teknologi serta seni secara serasi maka bangsa tersebut adalah bangsa yang beradab. Peradaban bangsa merupakan suatu istilah yang digunakan untuk menunjukkan kemajuan moral ilmu pengetahuan, teknologi, dan seni suatu bangsa. Paradaban bangsa adalah perkembangan kebudayaan suatu bangsa yang telah mencapai tingkat tertentu yang tercermin dalam tingkat intelektual, keindahan, teknologi, dan spiritual.

Untuk menjadi bangsa yang beradab, bangsa tersebut harus senantiasa menjunjung tinggi aturan, norma adat-istiadat, nilai-nilai kehidupan yang ada di masyarakat yang diwujudkan dengan menaati berbagai aturan sosial sehingga dalam kehidupan di masyarakat itu akan tercipta ketenangan, kenyamanan, ketenteraman, dan kedamaian.

Peradaban adalah bentuk budaya paling tinggi dari suatu kelompok masyarakat yang dibedakan secara nyata dari makhlukmakhluk lainnya. Peradaban mencerminkan kualitas kehidupan manusia dalam masyarakat. Kualitasnya diukur dari ketenteraman (human security), kedamaian (peacefull), keadilan (justice), dan kesejahteraan (welfare) yang merata (Nurihsan, 2016).

Kehancuran peradaban akibat degradasi akhlak telah banyak diberitakan melalui firman Allah SWT. Sebagai contoh, peradaban umat Nabi Nuh yang hancur akibat kekufuran mereka terhadap risalah tauhid yang disampaikan Nabi Nuh selama 950 tahun. Mereka dilanda banjir bandang (Q.S. Al-Ankabut: 14). Peradaban Madyan umat Nabi Syu'aib runtuh akibat praktik tipu daya dalam jual beli mereka. mereka ditimpa hawa panas (Q.S. At-Taubah: 70). Peradaban kaum Nabi Luth hancur dengan gempa bumi yang disertai angin kencang akibat praktik penyimpangan seks homoseksual (Q.S. Asy Syu'ara: 160).

Sepanjang sejarah peradaban manusia, moralitas, akhlak, dan budi pekerti selalu beriringan dengan jatuh bangunnya sebuah kaum. Peradaban Mesir Kuno hancur karena terjadi peperangan perebutan kekuasaan. Peradaban kuno di China juga runtuh karena mengalami beragam konflik dan intrik, perebutan kekuasaan, pemberontakan kepada kaisar yang lalim, dan perjanjian yang tidak adil. Peradaban Yunani Kuno hancur akibat saling menjatuhkan dan ambisi kekuasaan. Kemegahan peradaban 
Bangsa Romawi runtuh karena harta kekayaan yang dimiliki kaisar, membuat kerajaan selalu berfoyafoya dan pemerintahan Romawi diisi oleh orang yang tidak jelas kerjanya dan korup. Kejayaan Islam pada masa Dinasti Abbasiyah hancur karena moralitas elite dan sejumlah khalifah yang terlalu cinta dunia. Demikian pula Dinasti Ottoman di era modern, runtuh karena degradasi akhlak, baik karena sosok pemimpin yang lemah dan tidak berwibawa, pejabat kerajaan yang selalu hidup dalam kemewahan, penyimpangan keuangan, dan melemahnya semangat perjuangan para prajurit Utsmani. Sejumlah kerajaan Islam lainnya runtuh karena sebab dekadensi akhlak.

Mengutip pandangan Ibnu Khaldun, Nurihsan (2016) mengidentifikasi 10 faktor penyebab internal lemahnya dan runtuhnya peradaban yang bermuara pada degradasi akhlak, yaitu: 1) rusaknya akhlak penguasa; 2) penindasan penguasa dan ketidakadilan; 3) despotisme atau kezaliman; 4) orientasi kemewahan masyarakat; 5) egoisme; 6) oportunisme; 7) penarikan pajak secara berlebihan; 8) keikutsertaan penguasa dalam kegiatan ekonomi rakyat; 9) rendahnya peran masyarakat terhadap agama; dan 10) penggunaan pena dan pedang secara tidak tepat.

\section{Problematik Pendidikan}

\section{Berbasis Adab}

Pendidikan adalah alat utama untuk memperkuat budi warga dalam merawat bangsa. Dalam rumusan sistem pendidikan nasional, penyelenggaraan pendidikan nasional hadir tidak semata untuk membentuk manusia yang cerdas dan terampil, tetapi yang utama adalah menjadi manusia yang beriman dan bertakwa kepada Tuhan Yang Maha Esa, serta menjadi warga negara yang demokratis dan bertanggungjawab (Undang-Undang Republik Indonesia No. 20 Tahun 2003 Tentang Sistem Pendidikan Nasional, 2003). Di sanalah, urgensi peneguhan budi warga bangsa dikuatkan melalui pendidikan.

Pendidikan nasional berfungsi mengembangkan kemampuan dan membentuk watak serta peradaban bangsa yang bermartabat dalam rangka mencerdaskan kehidupan bangsa, bertujuan untuk berkembangnya potensi peserta didik agar menjadi manusia yang beriman dan bertakwa kepada Tuhan Yang Maha Esa, berakhlak mulia, sehat, berilmu, cakap, kreatif, mandiri, dan menjadi warga negara yang demokratis serta bertanggung jawab. Apabila kita cermati, rumusan “...membentuk manusia yang beriman dan bertakwa kepada Tuhan Yang Maha Esa...", berarti pendidikan nasional itu menempatkan keimanan sebagai fondasi dan tujuan pendidikan.

Mengutip pernyataan Mendikbud, di antara problematik pendidikan kebangsaan berbasis adab adalah keteladanan (Kompas, 2018). Banyak pakar bidang moral dan agama yang sehari-hari mengajar tentang kebaikan, tetapi perilakunya tidak sejalan dengan ilmu yang diajarkannya (Husaini, 2010). Sejak kecil anak-anak diajarkan menghafal tentang bagusnya sikap jujur, berani, kerja keras, kebersihan dan jahatnya kecurangan, tetapi nilai-nilai kebaikan itu diajarkan dan diujikan sebatas pengetahuan di atas kertas dan 
dihafal sebagai bahan yang wajib dipelajari, karena diduga akan keluar dalam kertas soal ujian. Begitu pentingnya soal adab ini maka sudah sepatutnya kurikulum pendidikan nasional -bagi kaum Muslim menyertakan pendidikan adab. Tujuannya tak lain agar para siswa menjadi beradab.

\section{Pendidikan Kebangsaan dan Indonesia Berkemajuan}

Pendidikan kebangsaan dan upaya mewujudkan Indonesia berkemajuan memiliki korelasi yang cukup erat. Pendidikan kebangsaan berbasis adab adalah pendidikan untuk pembinaan wawasan kebangsaan peserta didik yang berorientasi pada pembentukan warga negara yang memiliki rasa kebangsaan dan cinta tanah air yang dilandasi adab. Pendidikan kebangsaan ini adalah prasyarat bagi tercapainya cita-cita dan tujuan negara Indonesia yang berkemajuan.

Istilah Indonesia berkemajuan penulis derivasi dari pandangan kebangsaan Persyarikatan Muhammadiyah pada Muktamar ke47 di Makasar beberapa waktu yang lalu yang mengusung visi Indonesia Berkemajuan. Dalam pemikiran penulis, untuk menyongsong Visi Indonesia Berkemajuan, aspek pendidikan dan penyelenggaraan pendidikan pun harus berkemajuan. Pesan KH Ahmad Dahlan dalam membangun fondasi pendidikan agar "jadilah ulama yang berkemajuan, yakni yang memiliki ilmu pengetahuan agama dan ilmu pengetahuan umum yang luas dan jangan lelah, berhenti, memajukan bangsa dan masyarakat" menjadi penting dikaji secara teoretis dan diimplementasikan secara praksis.

Menanamkan adab dalam pendidikan kebangsaan merupakan perkara pokok dan utama yang harus ditempa oleh seorang guru kepada muridnya. Orang tua kepada anakanaknya. Jika adab ini sudah terpatri di dalam hatinya, maka akan tercermin dalam tingkah lakunya. Urgensi adab dan penanamannya pada anak terlihat lebih jelas lagi manakala kita melihat bahwa Rasulullah SAW memberikan perhatian besar terhadapnya di dalam pembinaan akhlak. Sampai-sampai beliau menjadikan penanaman adab pada anak dan membiasakan sehingga menjadi salah satu tabiat dan perangainya, lebih utama dari pada sedekah yang dapat memadamkan api. Padahal sedekah itu juga sangat penting dalam Islam. Rasulullah SAW kepada kedua orang tua bahwa hadiah terbesar bagi anak adalah adab, dan warisan termahal baginya adalah adab yang baik. Oleh karena itu Ali al-Madini Rahimahullah (Husaini, 2016) mengatakan mewariskan adab kepada anak-anak itu lebih baik bagi mereka daripada mewariskan harta. Adab bakal mendatangkan harta, kehormatan, cinta kepada sesama saudara serta akan menghimpunkan bagi mereka kebaikan dunia dan akhirat.

Tentang rumusan negara Indonesia berkemajuan, penulis merujuk pada rumusan pemikiran yang disampaikan Pimpinan Pusat Muhammadiyah dalam buku "Indonesia Berkemajuan: Rekonstruksi Kehidupan Kebangsaan yang Bermakna" (Pimpinan Pusat Muhammadiyah, 2015) yaitu sebagai berikut: 
Indonesia berkemajuan dapat dimaknai sebagai negara utama (al-madinal alfadhilah), negara berkemakmuran dan berkeadaban (umran), dan negara yang sejahtera. Negara berkemajuan adalah negara yang mendorong terciptanya fungsi kerisalahan dan kerahmatan yang didukung sumber daya manusia yang cerdas, berkepribadian, dan berkeadaban mulia (Nashir, 2015).

Rumusan di atas menegaskan cita-cita dan tujuan negara berkemajuan sebagai negara utama, berkemakmuran dan berkeadaban, serta negara yang sejahtera. Karena itu dalam pandangan Nashir (2015), konsekuensi dari negara berkemajuan tersebut adalah bahwa negara harus mampu menegakkan kedaulatan (wilayah, politik, hukum, ekonomi, dan budaya); mendatangkan kemakmuran (terpenuhinya kebutuhan sandang, pangan, dan papan); mewujudkan kebahagiaan material dan spiritual; menjamin kebebasan berpikir, berekspresi, dan beragama; menghormati hak asasi manusia; dan menciptakan keamanan dan jaminan masa depan. Artinya, negara sebagai organisasi kekuasaan tertinggi harus memiliki kedaulatan ke dalam dan keluar - agar mampu memenuhi hak-hak konstitusional warga negaranya.

Upaya pemenuhan hak-hak konstitusional warga negara oleh negara, sekaligus mensyaratkan perlunya upaya membangun keterlibatan warga dalam mewujudkan cita-cita dan tujuan
Indonesia berkemajuan di atas. Dengan demikian, pada setiap diri warga negara perlu dibangun pemahaman, keterampilan, dan sikap untuk melaksanakan kewajiban konstitusional sebagai warga negara, di samping menuntut hak konstitusional mereka sebagai warga negara. Keseimbangan antara pemenuhan hak dan pelaksanaan kewajiban konstitusional warga negara inilah yang melahirkan perlunya pendidikan kebangsaan bagi setiap warga negara.

\section{Islam dan Pendidikan Kebangsaan}

Islam adalah satu agama yang hidup dalam sebagian besar masyarakat bangsa Indonesia. Bukan itu saja, Islam adalah satu ideologi. Islam bukan semata-mata satu agama dalam arti hubungan manusia dengan Tuhan (Natsir, 2004). Sumber rujukan utama untuk menjelaskan Islam sebagai agama dan sistem nilai adalah al-Qur'an dan Sunah nabi yang sahih. Secara umum, Islam didefinisikan sebagai nama agama Allah (dienullah) yang diwahyukan kepada para Rasul-Nya sejak Nabi Adam AS sampai kepada Nabi Muhammad SAW (Ilyas, 2011). Secara khusus, Islam adalah nama diri dari agama yang dibawa oleh Nabi Muhammad SAW sebagai mata rantai akhir dari agama Allah yang diturunkan kepada umat manusia. Sebagai mata rantai akhir dari agama Allah, Islam yang dibawa oleh penutup para nabi ini telah disempurnakan dan dinyatakan oleh Allah sebagai agama yang diridlaiNya untuk seluruh umat manusia sampai hari akhir nanti.

Kedua, al-Islam adalah agama untuk penyerahan diri semata-mata 
kepada Allah, agama semua Nabinabi, agama yang sesuai dengan fitrah manusia, agama yang menjadi petunjuk bagi manusia, Agama yang mengatur hubungan manusia dengan Tuhan dan hubungan manusia dengan sesama, Agama yang menjadi rahmat bagi semesta alam. Islam satusatunya agama yang diridai Allah dan agama yang sempurna.

Dengan beragama Islam maka setiap muslim memiliki dasar/landasan hidup Tauhid kepada Allah, fungsi/peran dalam kehidupan berupa ibadah, dan menjalankan kekhalifahan, dan bertujuan untuk meraih Ridha serta Karunia Allah SWT. Islam yang mulia dan utama itu akan menjadi kenyataan dalam kehidupan di dunia apabila benarbenar diimani, dipahami, dihayati, dan diamalkan oleh seluruh pemeluknya (orang Islam, umat Islam) secara total atau kaffah dan penuh ketundukan atau penyerahan diri. Dengan pengamalan Islam yang sepenuh hati dan sungguh-sungguh itu maka terbentuk manusia muslimin yang memiliki sifat-sifat utama, yaitu berkepribadian muslim, berkepribadian mukmin, berkepribadian muhsin dalam arti berakhlak mulia, dan berkepribadian muttaqin.

Islam memiliki beberapa ciri khusus (Ilyas, 2011) sebagai berikut: 1) Islam adalah agama yang bersumber dari Allah SWT baik melalui wahyu secara langsung (Al Qur'an) maupun tidak langsung (Sunnah Nabawiyah) (QS 39:2; 32:2);

2) Ajaran Islam bersifat komprehensif (mencakup seluruh aspek kehidupan) (QS 6:38); 3) Ajaran Islam bersifat universal (berlaku untuk seluruh umat manusia sampai akhir zaman (QS 7:
158); 4) Ajaran Islam sesuai dengan fitrah manusia (QS 30:30); 5) Ajaran Islam menempatkan akal manusia pada tempat yang sebaik-baiknya secara proporsional, tidak mendewakan dan tidak pula menghinakannya (QS 7:179; 31:20); 6) Ajaran Islam menjadi rahmat bagi alam semesta (QS 21:107); 7) Ajaran Islam berorientasi ke masa depan (akhirat) tanpa melupakan masa kini (dunia) (QS 28:77); 8) Ajaran Islam menjanjikan surga bagi yang beriman dan neraka bagi yang kufur (QS 98:68).

Ajaran Islam bersifat menyeluruh yang satu dengan lainnya tidak dapat dipisah-pisahkan meliputi bidang-bidang akidah, akhlak, ibadah, dan mu'amalah duniawiyah. (Basyir, 2000; Ilyas, 2011; Nashir, 2013, 2015). Aqidah berisi aspek keyakinan terhadap Allah, para malaikat, kitab-kitab suci, para nabi dan rasul, hari akhir dan taqdir. Ibadah merupakan segala cara dan upacara pengabdian kepada Allah (ritual) yang telah diperintahkan dan diatur tata cara pelaksanaannya dalam Al Qur'an dan Sunah seperti shalat, puasa, zakat, haji dan sebagainya. Akhlak merupakan nilai dan perilaku baik yang harus diikuti seperti sabar, syukur, tawakal, berbakti pada kedua orang tua, berani dan lain sebagainya, serta nilai dan perilaku buruk yang harus dijauhi seperti sombong, takabur, dengki, riya, durhaka kepada kedua orang tua dan lain sebagainya. Mu'amalah adalah aspek kemasyarakatan yang mengatur pergaulan hidup manusia di atas bumi, baik tentang harta benda, perjanjian-perjanjian,

ketatanegaraan, hubungan antara negara dan lain sebagainya. 
Aspek aqidah, ibadah dan akhlak, dan sebagian kecil aspek mu'amalah (ahwal syakhksiyyah) dapat dikelompokkan ke dalam aspek nilai Islam yang statis. Artinya, ia tidak boleh mengalami perubahan sampai kapan pun. Tidak bolehnya mengalami perubahan "karena fungsinya sebagai dasar atau landasan normative yang membingkai dan mewarnai semua aspek kehidupan" (Ilyas, 2011). Sedangkan sebagian besar lainnya dari aspek mua'amalah bersifat dinamis, seperti politik, ekonomi, sosial budaya, pertahanan keamanan, dan lain-lain.

Karakteristik dan aspek-aspek Islam tersebut menunjukkan bahwa Islam adalah agama yang sangat lengkap mengatur seluruh aspek kehidupan manusia. Karena itu, nilainilai yang terkandung dalam agama Islam dapat diderivasi dalam program pendidikan untuk menumbuhkan wawasan kebangsaan. Tepatlah apa yang dikemukakan Mohammad Natsir, tokoh Islam dan mantan Perdana Menteri Republik Indonesia yang melihat bahwa Islam memelihara nilai yang ada, dan menumbuhkan yang belum ada (Natsir, 2004). Nilai-nilai itu antara lain: tolong menolong, nilai demokrasi dan musyawarah, mencintai tanah airnya, cinta kemerdekaan, kesukaan membela yang lemah, nilai tidak mementingkan diri sendiri dan kesediaan hidup dan memberi kehidupan, nilai toleransi antar pemeluk-pemeluk agama. Nilai-nilai tersebut adalah nilai-nilai kebajikan utama yang dapat dikembangkan melalui pendidikan kebangsaan.

\section{Reorientasi Pendidikan Kebangsaan dan Peran Guru}

Pendidikan

kebangsaan adalah pendidikan untuk membina wawasan kebangsaan warga negara. Pendidikan kebangsaan ini mengandung dua aspek utama, aspek moral dan aspek intelektual. Pada aspek moral berarti pendidikan kebangsaan mensyaratkan adanya perjanjian diri, adanya komitmen pada seseorang atau suatu masyarakat untuk turut bekerja bagi kelanjutan eksistensi bangsa serta bagi peningkatan kualitas kehidupan bangsa. Pada aspek intelektual, pendidikan kebangsaan menghendaki pengetahuan yang memadai tentang tantangan-tantangan yang dihadapi bangsa - baik sekarang maupun di masa yang akan dating - serta potensi-potensi yang dimiliki bangsa. Karena itu, Buchori (1994). menyebut ciri utama pendidikan kebangsaan watak moral-intelektual. Artinya, keseluruhan materi serta kegiatan yang terdapat di dalamnya harus benar-benar mampu membentuk kedua aspek kepribadian para peserta didik, yaitu aspek moral dan aspek intelektual. Kegiatan pendidikan kebangsaan harus mencakup tiga jenis kegiatan pembinaan, yaitu kegiatan-kegiatan untuk pembinaan daya kognitif, kegiatan-kegiatan untuk pembinaan daya afektif, dan kegiatan-kegiatan untuk pembinaan daya konatif.

Dalam pandangan

Kusumohamidjojo (1994), pendidikan kebangsaan harus disusun secara programatis dengan mengacu pada tiga sasaran utama, pencerahan (aufklaerung/enlightnenment), desektarianisasi, dan demokratisasi. 
Pencerahan dimaksudkan untuk mengembalikan acuan pandangan para warga bangsa kepada akal sehat dan dengan demikian membersihkan medan komunikasi sosial atau komunikasi antarwarga bangsa dari anasir-anasir agitatif atau propagandis yang selama ini ditunggangi oleh kepentingan terselubung dari aneka kekuatan sosial yang terkotak dalam masing-masing dogmatiknya sendiri. Desektariasisasi yaitu gerakan yang logisnya akan merupakan hasil dari pencerahan akan dank arena itu bertolak dari akal sehat sebagai acuan pandang untuk membangun wawasan kebangsaan para warga bangsa yang mandiri. Sedangkan demokratisasi, yaitu proses menuju pelibatan warga bangsa secara aktif dalam kehiduan kenegaraan integrative dan supra sectarian. Warga bangsa yang bebas dari jebakan sektarianisme atau separatism niscaya akan merupakan warga bangsa yang percaya kepada kemampuan rasionalnya masingmasing dan karena itu memiliki mentalitas mandiri dan bebas dari aneka kesetiaan sempit. Hanya warga bangsa yang mandiri yang mampu membangun peranannya yang aktif dan konstruktif atas dasar inisiatif sendiri dan yang berorientasi kepada kepentingan nasional.

Dari berbagai latar belakang rumusan pendidikan kebangsaan di atas, sebagai program kurikuler kewarganegaraan di persekolahan (school civic education), Kajian Pendidikan [Pancasila] dan Kewarganegaraan (Pancasila and Civic Education, PKn/PPKn) di Indonesia, dan pengalaman di beberapa negara lain di dunia, dapat dianggap memiliki misi sebagai pendidikan kebangsaan, yang berorientasi pada upaya pembentukan warga negara yang baik (be a good citizen), warga negara yang memiliki kebajikan/akhlak/budi utama sebagai bekal membangun negara utama.

Misi penyelenggaraan PPKn sebagai pendidikan kebangsaan tersirat dari pernyataan bagian Pendahuluan mata pelajaran PKn dalam Permendiknas No. 22 Tahun 2006 tentang Standar Isi.

Pendidikan di Indonesia diharapkan dapat mempersiapkan peserta didik menjadi warga negara yang memiliki komitmen kuat dan konsisten untuk mempertahankan Negara Kesatuan Republik Indonesia. Komitmen yang kuat dan konsisten terhadap prinsip dan semangat kebangsaan dalam kehidupan bermasyarakat, berbangsa, dan bernegara yang berdasarkan Pancasila dan Undang-Undang Dasar 1945, perlu ditingkatkan secara terus menerus untuk memberikan pemahaman yang mendalam tentang negara Kesatuan Republik Indonesia. Secara historis, negara Indonesia telah diciptakan sebagai Negara Kesatuan dengan bentuk Republik.

Dalam perkembangannya sejak Proklamasi 17 Agustus 1945 sampai dengan penghujung abad ke-20, rakyat Indonesia telah mengalami berbagai peristiwa yang mengancam keutuhan negara. Untuk itu diperlukan pemahaman yang mendalam dan komitmen yang kuat serta konsisten terhadap prinsip dan semangat kebangsaan dalam kehidupan bermasyarakat, berbangsa, dan bernegara yang berdasarkan pada Pancasila dan Undang-Undang Dasar 1945. Konstitusi Negara Republik Indonesia perlu ditanamkan kepada seluruh komponen bangsa Indonesia, 
khususnya generasi muda sebagai generasi penerus (Peraturan Menteri Pendidikan Nasional Republik Indonesia Nomor 22 Tahun 2006 tentang Standar Isi, 2006)

Dari rumusan tersebut, Winarno (2013) menyebut bahwa bagian pendahuluan itu secara jelas mengamanatkan pentingnya peserta didik sebagai generasi muda memiliki komitmen kuat terhadap negara kebangsaan modern Indonesia, serta prinsip semangat kebangsaan yang kuat dalam kehidupan berbangsa dan bernegara. Sebagai negara Indonesia sebagai negara kebangsaan modern merupakan consensus bersama yang perlu dipertahankan dan pengalaman bersama pula telah banyak berbagai peristiwa yang mengancam keutuhan bangsa. Sikap dan komitmen kebangsaan itu dapat ditumbuhkan melalui mata pelajaran PPKn.

Rumusan resmi tentang kajian PPKn dewasa ini menyebutkan:

Mata pelajaran PPKn memiliki visi dan misi mengembangkan siswa menjadi warga negara yang baik yang memiliki rasa kebanggaan terhadap Negara Indonesia, cinta tanah air, jujur, disiplin, tanggung jawab, santun, peduli, dan percaya diri dalam berinteraksi di lingkungan rumah, sekolah, dan sekitarnya serta berbangsa dan bernegara (Kementerian Pendidikan dan Kebudayaan Republik Indonesia, 2016).

Dari rumusan tersebut, kompetensi setelah mempelajari mata pelajaran PPKn di Pendidikan Dasar dan Menengah adalah sebagai berikut:

a. Bertanggung jawab pada setiap keputusan bersama berdasar nilai-nilai Pancasila sebagai Dasar Negara dan penghargaan atas kewajiban dan hak warga negara dalam kehidupan berbangsa dan bernegara,

b. Melaksanakan kewajiban, hak, dan tanggung jawab sebagai warga negara yang mendukung pelindungan dan penegakkan hukum dalam menjamin keadilan dan kedamaian berdasar UndangUndang Dasar Negara Republik Indonesia Tahun 1945,

c. Bertoleransi terhadap masalah-masalah dalam bidang sosial, budaya, ekonomi, dan gender, serta mengantisipasi pengaruh positif dan negatif kemajuan iptek terhadap negara dalam bingkai Bhinneka Tunggal Ika,

d. Mempertahankan persatuan dan kesatuan bangsa sebagai wujud rasa cinta dan bangga dalam upaya menjaga dan mempertahankan Negara Kesatuan Republik Indonesia (NKRI) (Kementerian Pendidikan dan Kebudayaan Republik Indonesia, 2016).

Pada setiap jenjang pendidikan, berdasarkan pada aspek materi PPKn, maka kompetensi yang harus dicapai siswa setelah mempelajari PPKn di sekolah adalah tergambar seperti tabel berikut: 
Tabel 1: Kompetensi setelah mempelajari PPKn

\begin{tabular}{|c|c|c|c|}
\hline Kelas Rendah & Kelas Tinggi & SMP & SMA \\
\hline $\begin{array}{l}\text { Mencintai lambang } \\
\text { garuda Pancasila } \\
\text { sebagai dasar } \\
\text { Negara Indonesia }\end{array}$ & $\begin{array}{l}\text { Berperilaku sesuai } \\
\text { nilai-nilai Pancasila } \\
\text { yang merupakan } \\
\text { dasar Negara } \\
\text { Indonesia }\end{array}$ & $\begin{array}{l}\text { Berintegritas sesuai } \\
\text { dengan nilai-nilai } \\
\text { Pancasila dalam } \\
\text { kehidupan } \\
\text { berbangsa dan } \\
\text { bernegara }\end{array}$ & $\begin{array}{l}\text { Bangga sebagai } \\
\text { bangsa Indonesia } \\
\text { yang menghargai } \\
\text { kewajiban dan hak } \\
\text { sesuai dengan nilai- } \\
\text { nilai Pancasila }\end{array}$ \\
\hline $\begin{array}{l}\text { Bekerja sama } \\
\text { melaksanakan } \\
\text { kewajiban dan } \\
\text { memenuhi hak } \\
\text { masing-masing } \\
\text { dengan penuh } \\
\text { percaya diri sebagai } \\
\text { anggota keluarga } \\
\text { dan warga sekolah }\end{array}$ & $\begin{array}{l}\text { Melaksanakan } \\
\text { kewajiban dengan } \\
\text { penuh } \\
\text { tanggungjawab } \\
\text { serta peduli } \\
\text { terhadap hak yang } \\
\text { dimilikinya sebagai } \\
\text { anggota masyarakat }\end{array}$ & $\begin{array}{l}\text { Berperan serta } \\
\text { dalam menjaga } \\
\text { kedaulatan Negara } \\
\text { sesuai dengan } \\
\text { Undang-undang } \\
\text { Dasar Negara } \\
\text { Republik Indonesia } \\
\text { tahun } 1945\end{array}$ & $\begin{array}{l}\text { Berpartisipasi aktif } \\
\text { dalam upaya } \\
\text { pelindungan dan } \\
\text { penegakan hukum } \\
\text { untuk menciptakan } \\
\text { kedamaian di } \\
\text { Negara Republik } \\
\text { Indonesia }\end{array}$ \\
\hline $\begin{array}{l}\text { Bertanggungjawab } \\
\text { melaksanakan } \\
\text { berbagai aktivitas } \\
\text { dalam suasana } \\
\text { kebersamaan di } \\
\text { kehidupan yang } \\
\text { beragam }\end{array}$ & $\begin{array}{l}\text { Berperan serta } \\
\text { dalam } \\
\text { melaksanakan } \\
\text { berbagai aktivitas } \\
\text { yang beragam } \\
\text { dengan penuh } \\
\text { percaya diri di } \\
\text { masyarakat }\end{array}$ & $\begin{array}{l}\text { Mendukung } \\
\text { persatuan dan } \\
\text { kesatuan dalam } \\
\text { menyelesaikan } \\
\text { masalah nasional }\end{array}$ & $\begin{array}{l}\text { Bangga sebagai } \\
\text { bangsa Indonesia } \\
\text { yang mampu } \\
\text { berperan dalam } \\
\text { kemajuan IPTEK } \\
\text { (Ilmu Pengetahuan } \\
\text { dan Teknologi) } \\
\text { dalam konteks } \\
\text { lokal dan global }\end{array}$ \\
\hline $\begin{array}{l}\text { Mengenali dirinya } \\
\text { dalam keberagaman } \\
\text { anggota keluarga, } \\
\text { teman di sekolah } \\
\text { dan teman bermain } \\
\text { di lingkungannya }\end{array}$ & $\begin{array}{l}\text { Bertanggungjawab } \\
\text { untuk menjaga } \\
\text { persatuan dan } \\
\text { kesatuan dalam } \\
\text { keberagaman } \\
\text { kehidupan di } \\
\text { masyarakat }\end{array}$ & $\begin{array}{l}\text { Mencintai Negara } \\
\text { Kesatuan Republik } \\
\text { Indonesia dengan } \\
\text { membela } \\
\text { kebenaran, } \\
\text { persatuan dan } \\
\text { kesatuan di } \\
\text { lingkungannya }\end{array}$ & $\begin{array}{l}\text { Berperan aktif } \\
\text { dalam menjaga dan } \\
\text { mempertahankan } \\
\text { persatuan dan } \\
\text { kesatuan Negara } \\
\text { Kesatuan Republik } \\
\text { Indonesia dengan } \\
\text { berpikir dan } \\
\text { berperilaku positif }\end{array}$ \\
\hline
\end{tabular}

Sumber: (Kementerian Pendidikan dan Kebudayaan Republik Indonesia, 2016)

Dari uraian di atas, yang dimaksud reorientasi pendidikan kebangsaan adalah penyelenggaraan pendidikan kebangsaan melalui program kurikuler kewarganegaraan (school civic education) dengan mengangkat, mengintegrasikan, dan menguatkan nilai-nilai Islam (terutama aspek akhlak/budi/kebajikan utama) pada kajian PPKn. Penguatan nilai-nilai Islam dalam program kurikuler kewarganegaraan memiliki pijakan yang cukup kuat. Sebab nilai-nilai akhlak/budi/kebajikan utama Islam yang dipelihara dan tumbuh dalam konteks kenegaraan bersifat komprehensif (mencakup semua aspek kehidupan manusia), berlaku universal, dan menjadi rahmat bagi semesta alam.

\section{Perkataan}

budi/akhlak/kebajikan utama sesungguhnya adalah sifat yang 
tertanam dalam jiwa yang menimbulkan perbuatan-perbuatan dengan gampang dan mudah, tanpa memerlukan pemikiran dan pertimbangan. Akhlak haruslah bersifat konstan, spontan, tidak temporer dan tidak memerlukan pemikiran dan pertimbangan serta dorongan dari luar (Ilyas, 2015). Dengan demikian, budi/akhlak/kebajikan utama kewargaan sesungguhnya adalah sikap dan perilaku warga negara yang bersifat konstan, spontan, tidak temporer dan tidak memerlukan pemikiran dan pertimbangan, serta dorongan dari luar. Dilihat dari ruang lingkupnya, dengan merujuk pada pendapat Muhammad Abdullah Draz, Ilyas (2015) menyatakan bahwa akhlak (kewargaan) dalam perspektif Islam dapat dikelompokkan ke dalam lima bagian: akhlak pribadi, akhlak berkeluarga, akhlak bermasyarakat, akhlak bernegara, dan akhlak beragama. Dengan demikian, akhlak kewargaan, sebagaimana kita sebut sebagai komponen penting budaya kewargaan bagi terwujudnya masyarakat demokrasi Indonesia yang kuat, mencakup spektrum yang luas, meliputi seluruh aspek kehidupan, baik secara vertikal dengan Allah SWT maupun secara horizontal sesama makhluk-Nya.

Mengangkat nilai-nilai budi/akhlak/kebajikan utama yang bersumber dari nilai-nilai Islam dalam kajian PPKn - sebagai pendidikan kebangsaan - juga untuk menguatkan aspek moral dan aspek intelektual pendidikan kebangsaan yang berbasis nilai-nilai Islam pada tiga ranah pembinaan, kognitif, afektif dan konatif. Dalam konteks itu, penulis ingin mengajak para komunitas akademik dan praktisi PPKn untuk mengangkat nilai-nilai Islam dalam kajian kurikuler kewarganegaraan. Klaim kebenaran Islam diangkat dalam kajian pendidikan kebangsaan yang berkemajuan sebagai energi positif untuk kehidupan berbangsa dan bernegara yang plural dan heterogen. Samsuri (Samsuri, 2011) menyebut mengajarkan kebenaran agama adalah suatu keharusan bagi pemelukpemeluknya. Karena "kebenaran agama" memberikan jaminan bagi para pengikutnya dalam menjalankan keyakinannya itu. Persoalannya, bagaimana "klaim kebenaran agama" tidak menjadi sumber konflik dan perpecahan, tetapi klaim itu menjadi energi positif untuk kehidupan berbangsa dan bernegara yang majemuk. Banyak ikhtiar telah dilakukan, termasuk pembinaan moralitas agama sebagai fondasi kehidupan berbangsa dan bernegara di lingkungan sekolah, keluarga dan masyarakat agar pendidikan kebangsaan benar-benar efektif.

Lalu bagaimanakah guru yang dapat berperan membangun peradaban? Guru mempunyai peran yang sangat strategis dalam membangun peradaban bangsa. Mengutip pandangan Makmun, Nurihsan (2016) menyebut bahwa peran guru dalam membangun peradaban bangsa meliputi sebagai konservator (pemelihara) sistem nilai; sebagai transmiter (penerus) sistem nilai; sebagai transformator (penerjemah) sistem nilai; dan sebagai organisator (penyelenggara) terciptanya proses pendidikan dalam membangun peradaban bangsa.

Agar dapat menjadi teladan bagi bangsanya, guru harus 
menunjukkan kepribadiannya secara efektif. Tidak hanya dirinya yang harus menjadi teladan, akan tetapi kehidupan keluarganya pun harus menjadi teladan bagi bangsanya. Sebagai agen masyarakat, guru berperan sebagai mediator antara masyarakat dengan dunia pendidikan dalam membangun peradaban bangsa. Dalam kaitan ini, guru sebagai pembawa (transporter) berbagai inovasi dalam ilmu pengetahuan, teknologi, dan seni dari sekolah ke dalam masyarakat dan juga membawa kehidupan masyarakat yang beradab ke sekolah. Selanjutnya sebagai pendidik masyarakat, guru bersama unsur masyarakat lainnya mengembangkan berbagai upaya pendidikan yang dapat menunjang upaya membangun peradaban bangsa. Untuk mewujudkan upaya pembangunan peradaban bangsa ini guru dituntut profesional.

Berkaitan dengan kemampuan profesional guru, Johnson (Nurihsan, 2016) menyebut ada enam komponen kemampuan profesional yang perlu dimiliki guru, yaitu: 1) Unjuk kerja (performance); 2) Penguasaan materi pelajaran yang harus diajarkan kepada siswanya; 3) Penguasaan landasan profesional keguruan dan kependidikan; 4) Penguasaan prosesproses pengajaran dan pendidikan; 5) Penguasaan cara-cara untuk menyesuaikan diri; dan 6) Kepribadian. Keenam komponen kualitas kemampuan guru itu tidak boleh dipandang sebagai pilahanpilahan yang terpisah, melainkan harus dipandang sebagai suatu keterpaduan yang menjelma dan bermuara pada kualitas unjuk kerjanya yang diperkirakan menunjang keberhasilan siswa dalam belajar. Di samping itu, proporsi setiap komponen dalam keseluruhan kemampuan itu tidak sama besar tergantung pada penekanannya.

Ketika menjelaskan tentang sifat dalam bekerja untuk guru, Hamka (2016a, hal. 115-116) menguraikan sifat guru yang sukses dalam bekerja sebagai berikut: "Guru yang mendapat sukses di dalam pekerjaannya dan mendidik muridnya mencapai kemajuan, ialah guru yang tidak hanya mencukupkan ilmunya dari sekolah guru saja, tetapi diperluasnya pengalaman dan bacaan. Senantiasa teguh hubungannya dengan kemajuan modern dan luas pergaulannya, baik dengan wali murid atau dengan sesama guru, sehingga bisa menambah ilmu tentang soal pendidikan. Akrab hubungannya dengan orang-orang tua dan golongan muda supaya dia sanggup mempertalikan zaman lama dengan zaman baru, dan dapat disisihkannya mana yang antah dan mana yang beras. Dia menjadi penunjuk bagi muridnya, pembuka kunci akalnya dan memperluas lapangan usahanya".

Sifat guru dalam bekerja tersebut adalah cerminan dari keterangan ayat Al-Qur'an yang mengingatkan, "Serulah (manusia) kepada jalan Tuhan-mu dengan hikmah (ilmu pengetahuan), pelajaran yang baik, dan bantahlah mereka dengan cara yang baik. Sesungguhnya Tuhanmu Dialah yang lebih mengetahui tentang siapa yang tersesat dari jalan-Nya dan Dialah yang lebih mengetahui orang-orang yang mendapat petunjuk." (QS. Surah An-Nahl [16]: 125). 
Sementara itu, berkaitan dengan hubungan guru dengan orang tua murid. Hamka (2016b, hal. 306) secara rinci menjelaskan sebagai berikut:

Didikan di sekolah bertalian dengan didikan di rumah. Hendaklah ada kontak yang baik antara orang tua murid dengan guru. Antara orang tua dan guru perlu datang mendatangi, ziarah menziarahi, selidik menyelidiki tentang tabiat anak yang di dalam didikan itu. ...kesempurnaan didikan anak itu dapat dibicarakan dengan baik.

Demikian pentingnya penggambaran hubungan guru dan orang tua murid dalam proses pendidikan seorang anak tersebut menunjukkan bahwa guru dan orang tua murid memiliki andil besar dalam mencapai kesuksesan anak didiknya. Hamka (2016b, hal. 306) menyebut "kepandaian orang tua mendidik anak, adalah menjadi penolong guru. Sebaliknya, jika anak itu hanya dilepas 'unggaskan' saja oleh ayah bundanya, diserahkan saja pada guru, disangkanya dapat guru itu memimpin sendiri dan dia bersikap 'masa bodoh', jaranglah berhasil apa yang diharap".

Guru merupakan elemen penting dalam upaya mengajak umat Islam untuk mengembangkan ilmu pengetahuan yang berguna bagi peradaban. Sebab, tanpa kontribusi guru, peradaban sulit untuk direalisasikan. Guru juga bertugas mewujudkan dunia pendidikan yang memanusiakan manusia. Artinya, dalam melaksanakan tugasnya, seorang guru harus berorientasi pada upaya mewujudkan nilai-nilai kemanusiaan yang dilandasi ajaran Islam. Di samping itu, tugas guru juga termasuk memotivasi dan menumbuhkan semangat mencari ilmu peserta didik.

Oleh karena itu, Islam sangat mengajurkan seseorang menjadi guru yang memiliki kedalaman ilmu yang luas. Sebagaimana yang terpadat dalam penjelasan hadis nabi, "Jadilah engkau orang berilmu, atau orang yang menuntut ilmu, atau orang yang mau mendengarkan ilmu, atau orang yang menyukai ilmu. Dan janganlah engkau menjadi orang yang kelima maka kamu akan celaka" (HR. Baihaqi). Bahkan dalam hadis Nabi yang lain dijelaskan, "Tinta para ulama lebih tinggi nilainya daripada darah para syuhada." (HR. Abu Daud dan Turmizi).

Demikian pentingnya tugas seorang guru, Rasulullah bersabda, "Sesungguhnya Allah dan malaikat, penghuni langit serta bumi termasuk semut yang berada di dalam lubangnya dan ikan-ikan (di lautan) berselawat ke atas guru yang mengajar kebaikan kepada manusia." (HR. Tarmidzi)

Bagi Natsir pendidikan harus bermuara pada prinsip tauhid kepada Allah SWT. Ia menguraikan dengan cukup jelas:

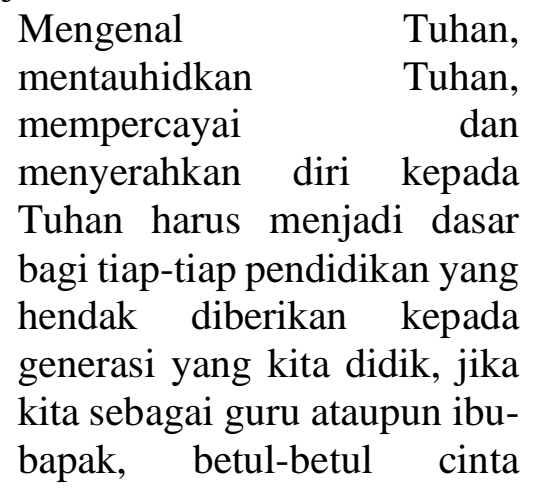


kepada anak-anak yang telah dipercayakan Allah kepada kita itu (Natsir, 1973, hal. 142).

Tugas utama guru dalam mewujudkan peradaban Islam tidak lain adalah membina umat Islam seutuhnya secara pribadi, kelompok, dan masyarakat- agar umat Islam dapat menjalankan ajaran Islam secara komprehensif. Selain itu, tugas guru sebagai khalifah dan hamba Allah adalah membangun peradaban dunia sesuai dengan konsep yang ditetapkan Allah SWT.

Firman Allah SWT yang tercantum dalam Al-Qur'an secara tegas menyebutkan, "Kamu adalah umat yang terbaik yang dilahirkan untuk manusia, menyuruh kepada yang ma'ruf, mencegah yang munkar, dan beriman kepada Allah. Sekiranya Ahli Kitab beriman, tentulah itu lebih baik bagi mereka. Di antara mereka ada yang beriman, dan kebanyakan mereka adalah orang-orang yang fasik." (QS. Ali-Imran [3]: 110). Berdasarkan keterangan tersebut, para guru dapat dikategorikan sebagai umat terbaik yang bertugas mewujudkan visi-misi pendidikan (Islam). Seperti mendidik masyarakat dengan mengajarkan pengetahuan yang dilandasi nilai-nilai moral agama. Guru juga mencegah masyarakat berbuat keburukan dengan menggunakan pendekatan ilmu, dialog yang bermartabat, dan memberikan teladan yang baik. Sehingga tercipta generasi Islam yang memiliki keseimbangan antara ilmu, iman, dan amal.

\section{SIMPULAN}

Penyelenggaraan pendidikan kebangsaan berbasis adab, sebagai pendidikan yang bersandar pada nilainilai budi/akhlak/kebajikan utama warga negara, atau pendidikan untuk pembinaan wawasan kebangsaan yang berbasis nilai-nilai Islam merupakan ikhtiar untuk menjaga dan merawat rajutan kebangsaan Indonesia yang bersatu di atas dasar falsafah Pancasila dan dasar konstitusional UUD 1945. Menawarkan adab Islam sebagai acuan bagi penguatan budi/akhlak/kebajikan utama dalam rangka penguatan wawasan kebangsaan melalui kajian kurikuler kewarganegaraan tentu saja memerlukan komitmen dari seluruh komunitas akademik PPKn. Diperlukan kajian-kajian akademis pedagogis untuk praxis penyelenggaraan pendidikan kebangsaan yang berkemajuan. Sehingga, pada gilirannya nanti, kajian kurikuler kewarganegaraan yang mengemban misi pendidikan kebangsaan menjadi bidang kajian yang kuat dan berkontribusi besar bagi penguatan budi/akhlak/ kebajikan utama warga negara demi terwujudnya cita-cita dan tujuan Indonesia berkemajuan. 


\section{DAFTAR PUSTAKA}

Ahmadi, A., \& Uhbiyati, N. (1991). Ilmu pendidikan. Jakarta: Rineka Cipta.

Al-Attas, S. M. N. (2001). Risalah untuk kaum muslimin. Kuala Lumpur: ISTAC.

Basyir, A. A. (2000). Negara dan Pemerintahan dalam Islam. Yogyakarta: UI Press.

Buchori, M. (1994). Pendidikan wawasan kebangsaan: Masalah program dan metode. In S. Poespowardojo \& F. M. Parera (Ed.), Pendidikan Wawasan Kebangsaan: Tantangan dan Dinamika Perjuangan kaum Cendekiawan Indonesia (hal. 233-244). Jakarta: Kerja sama Lembaga Pengkajian Strategis dan Pembangunan (LPSP) dengan Penerbit PT Gramedia Widasarana Indonesia.

CNN Indonesia. (2018). Bank Dunia: Kualitas Pendidikan Indonesia Masih Rendah. Diambil 1 Januari 2019, dari https://www.cnnindonesia.com/gayahidup/20180607113429-284-304214/bank-dunia-kualitas-pendidikanindonesia-masih-rendah

Daud, W. M. N. W. (1998). Filsafat dan praktik pendidikan Islam Syed M. Nauquib Al-Attas. Bandung: Mizan.

Dhakidae, D. (2002). Pengantar: Memahami Rasa Kebangsaan dan Menyimak Bangsa sebagai Komunitas-Komunitas Terbayang. In Imagined Communities (Komunitas-komunitas Terbayang). Yogyakarta: Kerja sama INSIST dan Pustaka Pelajar.

Hamka. (2016a). Lembaga budi (1, Januari ed.). Jakarta: Republika Penerbit.

Hamka. (2016b). Lembaga hidup (2 ed.). Jakarta: Republika Penerbit.

Hamka. (2017). Renungan tasawuf. Jakarta: Republika Penerbit.

Henderson, S. van P. (1959). Introduction to philosophy of education. Chicago: The University of Chicago Press.

Husaini, A. (2010). Pendidikan: Membentuk manusia berkarakter dan beradab. In Seminar Nasional Pendidikan Karakter Membangun Bangsa Beradab. Bandung: Program Studi Pendidikan Umum Sekolah Pascasarjana UPI.

Husaini, A. (Ed.). (2016). Pendidikan berbasis adab: Konsep dan aplikasi di Pesantren at-Taqwa (Pesantren Shoul Lin al-Islami) Depok (Vol. 1). Depok: Attaqwa Press Depok.

Ilyas, Y. (2011). Cakrawala al Qur'an: Tafsir tematis tentang berbagai aspek kehidupan. Yogyakarta: Itqan Publishing.

Ilyas, Y. (2015). Kuliah akhlaq. Yogyakarta: Lembaga Pengkajian dan Pengamalan Islam (LPPI) UMY.

Kementerian Pendidikan dan Kebudayaan Republik Indonesia. (2016). Silabus Mata Pelajaran SMP/MTs: Mata Pelajaran Pendidikan Pancasila dan Kewarganegaraan. Jakarta: Kementerian Pendidikan dan Kebudayaan 
Republik Indonesia.

Kompas. (2018). Mendikbud: Problem Pendidikan Saat Ini, Kurangnya Keteladanan! - Kompas.com. Diambil 1 Januari 2019, dari https://edukasi.kompas.com/read/2018/08/16/20172561/mendikbud-problempendidikan-saat-ini-kurangnya-keteladanan

Kusumohamidjojo, B. (1994). Kata Pengantar. In S. Poespowardojo \& F. M. Parera (Ed.), Pendidikan wawasan kebangsaan: Tantangan dan dinamika perjuangan kaum cendekiawan Indonesia (hal. xv-xix). Jakarta: Kerja sama Lembaga Pengkajian Strategis dan Pembangunan (LPSP) dengan Penerbit PT Gramedia Widasarana Indonesia.

Langeveld, M. J. (1965). Pengantar pedagogik teoretis (Terjemahan). Bandung: Bapemsi.

Maarif, A. S. (2015). Pengantar LPPI. In Kuliah akhlaq. Yogyakarta: Lembaga Pengkajian dan Pengamalan Islam (LPPI) UMY.

Marimba, A. D. (1989). Pengantar filsafat pendidikan. Bandung: PT Al Ma'arif.

Nadlir, M. (2018). Komnas HAM Catat 4 Kondisi Darurat Pendidikan Indonesia Kompas.com. Diambil 1 Januari 2019, dari https://nasional.kompas.com/read/2018/05/02/12581141/komnas-ham-catat4-kondisi-darurat-pendidikan-indonesia

Nashir, H. (2013). Islam Syariat. Bandung: Mizan.

Nashir, H. (2015). Muhammadiyah dan rekonstruksi politik kebangsaan. Suara Muhammadiyah, 12-14.

Natsir, M. (1973). Capita selecta I (3 ed.). Jakarta: Bulan Bintang.

Natsir, M. (2004). Islam sebagai Dasar Negara. (K. O. Santosa, Ed.). Bandung: Sega Arsy.

Nurihsan, A. J. (2016). Membangun peradaban melalui pendidikan dan bimbingan. Bandung: PT Refika Aditama.

Peraturan Menteri Pendidikan Nasional Republik Indonesia Nomor 22 Tahun 2006 tentang Standar Isi (2006).

Pimpinan Pusat Muhammadiyah. (2015). Indonesia berkemajuan: Rekonstruksi kehidupan kebangsaan yang bermakna (Muktamar k). Yogyakarta: Pimpinan Pusat Muhammadiyah.

Q-Anees, B., \& Hambali, A. (2008). Pendidikan karakter berbasis al-quran. Bandung: Simbiosa Rekatama Media.

Rasyidin, W. (2007). Pedagogik teoretis. In M. Ali, R. Ibrahim, N. S. Sukmadinata, D. Sudjana, \& W. Rasyidin (Ed.), Ilmu dan Aplikasi Pendidikan (1 ed., hal. 33-52). Bandung: Pedagogiana Press.

Republika. (2018). Survei: Anak-Anak Rentan Terlibat Paham Radikalisme Republika Online. Diambil 2 Januari 2019, dari 
https://www.republika.co.id/berita/nasional/hukum/18/05/16/p8s5hd330survei-anakanak-rentan-terlibat-paham-radikalisme

Saduloh, U. (2004). Pengantar filsafat pendidikan. Bandung: Alfabeta.

Samsuri. (2011). Pendidikan Karakter: Menyemai Moralitas Agama dan Kenegarawanan. In Seminar Nasional Pendidikan "Revitalisasi Pendidikan Karakter menuju Progresivitas Pendidikan Nasional" (hal. 1-10). Purwokerto: Universitas Muhammadiyah Purwokerto.

Shihab, M. Q. (1992). Membumikan al-qur'an. Bandung: Mizan.

Sudjana, N. (1988). Pembinaan dan pengembangan kurikulum di sekolah. Bandung: Sinar Baru Algesindo.

Tafsir, A. (2004). Ilmu pendidikan dalam perspektif Islam. Bandung: Remaja Rosdakarya.

Taftazani, I. S., \& Abdurrahman, M. (2005). Konsep tarbiyat (pendidikan) dalam al-quran: Sebuah kajian semantis berdasar ayat-ayat al-quran. Bandung. Diambil

dari http://file.upi.edu/Direktori/FPBS/JUR._PEND._BAHASA_ARAB/1961061 81987031-MAMAN_ABDURAHMAN/KonsepPENDinQURANhstMAR.pdf

Undang-Undang Republik Indonesia No. 20 Tahun 2003 Tentang Sistem Pendidikan Nasional (2003).

Winarno. (2013). Pembelajaran pendidikan kewarganegaraan. Isi, strategi dan penilaian. Jakarta: PT. Bumi Aksara. 